\title{
PENERAPAN METODE ANALYTICAL HIERARCHY PROCESS (AHP) DAN SIMPLE ADDITIVE WEIGHTING (SAW) DALAM SISTEM PENUNJANG KEPUTUSAN PENENTUAN GURU TERBAIK PADA SMPN 10 TANGERANG
}

\author{
Anto Prasetyo ${ }^{1)}$, Lusi Fajarita ${ }^{2)}$ \\ ${ }^{1}$ Sistem Informasi, Fakultas Teknologi Informasi, Universitas Budi Luhur \\ ${ }^{1,2} \mathrm{Jl}$. Raya Ciledug, Petukangan Utara, Kebayoran Lama, Jakarta Selatan 12260 \\ E-mail : antoprasetyo020@gmail.com ${ }^{1)}$, lusi.fajarita@budiluhur.ac.id ${ }^{2}$
}

\begin{abstract}
Abstrak
Penentuan guru terbaik merupakan hak prerogatif Kepala Sekolah kepada guru yang memenuhi kriteria yang telah ditetapkan. Namun dalam memberikan penilaian tersebut, tidak memungkiri akan adanya penilaian secara subyektif karena satu dan lain hal. Sistem penunjang keputusan merupakan suatu sistem yang dapat menghasilkan informasi yang spesifik untuk membantu Top Level Management dalam mengambil keputusan. Dengan sistem ini maka penilaian secara subyektif dapat diminimalisir. Penggabungan metode Analytical Hierarchy Process (AHP) Dan Simple Additive Weighting (SAW) digunakan untuk menentukan bobot penilaian dan menghasilkan nilai alternatif terbaik. Pada prinsipnya metode AHP akan memecahkan persoalan dengan 3 cara yaitu: menyusun hirarki, menentukan prioritas dan mengukur konsistensi. Sedangkan metode SAW akan mencari penjumlahan terbobot dari rating kinerja setiap alternatif disemua atribut. Dalam penelitian ini, kriteria yang dinilai dalam penentuan guru terbaik antara lain : pedagogik, sosial, kepribadian dan profesional. Dimana pada setiap kriteria tersebut memiliki beberapa sub kriteria. Hasil pengujian sistem pada semua kriteria yang dinilai, dengan metode AHP menghasilkan nilai Consistency Index (CI) dan Consistency Ratio (CR) yang konsisten, yaitu kurang dari 0,1. Hasil pengujian dengan metode SAW terhadap 5 orang guru yang dinilai, menghasilkan peringkat pertama dengan nilai tertinggi sebesar 3,6859.
\end{abstract}

Kata kunci: AHP, DSS, Eigenvector, SAW.

\section{PENDAHULUAN}

Pendidikan merupakan salah satu aspek yang dapat membantu sebuah bangsa dalam menghadapi persaingan dalam sisi SDMnya. Tidak dapat dipugkiri bahwa pendidikan juga dapat dijadikan sebagai nilai unggul dalam membawa diri ketika sedang menghadapi competitor. Adapun pihak yang mempengaruhi keberhasilan pendidikan, antara lain: guru, siswa, sarana dan prasarana, lingkungan pendidikan, dan kurikulum. Dari berbagai faktor tersebut, guru merupakan peranan yang paling penting dan yang paling berpengaruh dalam dunia pendidikan pada proses kegiatan belajar mengajar di kelas, karena guru sangat berpengaruh untuk menentukan keberhasilan siswa/siswi dimasa yang akan mendatang. Guru yang mempunyai kinerja yang baik akan mampu menumbuhkan semangat dan motivasi belajar siswa/siswi yang lebih baik, yang pada akhirnya akan meningkatkan kualitas pembelajaran. Untuk memberikan penghargaan kepada guru yang sudah memberkan yang terbaik kepada anak didiknya, maka SMPN 10 Tangerang melakukan kegiatan penilaian dalam penentuan guru terbaik. Untuk menghindari adanya penilaian secara subyektif, maka dibutuhkan sistem penunjang keputusan untuk menghindari penilaian yang masih bersifat subjektif..
Sistem pendukung keputusan atau Decision Support Sytem (DSS) adalah sistem berbasis komputer yang membantu para pengambil keputusan mengatasi berbagai masalah melalui interaksi langsung dengan sejumlah basis data (database) dan perangkat lunak analitik. Salah satu tujuan dari system penunjang keputusan adalah memberikan dukungan kepada pihak manajerial dalam pengambilan keputusan .

\section{METODE PENELITIAN}

Untuk menghasilkan penelitian yang sesuai dengan tujuan, langkah yang dilakukan antara lain :

a. Observasi, dengan melakukan pengamatan langsung ke objek penelitian.

b. Wawancara, dengan melakukan tanya jawab ke pihak yang secara langsung menilai kinerja guru dan mengeluarkan surat keputusan.

c. Analisa Dokumen, dengan mengumpulkan dokumen-dokumen yang berkaitan dengan penilaian guru seperti form penilaian kinerja guru dan berkas rekapan hasil penilaian kinerja guru.

d. Kuesioner, dengan mengajukan pertanyaan tertulis kepada pihak sekolah terkait dengan penentuan kriteria penilaian. 
e. Studi Literatur, dengan melakukan komparasi dengan penelitian-penelitian sejenis yang sudah pernah dilakukan sebelumnya.

\section{HASIL DAN PEMBAHASAN}

Pembuatan sistem penunjang keputusan ini menggunakan kombinasi 2 metode yaitu $A H P$ dan SAW.

\subsection{Metode Analytical Hierarchy Process (AHP)}

Metode ini berfungsi untuk memecahkan masalah yang kompleks menjadi sub-sub masalah lalu menyusunnya ke dalam bentuk hierarki . Tahapan yang dilakukan dengan metode ini untuk menghasilkan nilai akhir tertinggi dari semua guru yang dinilai antara lain :

1. Mendefinisikan masalah dan menentukan solusi

Masalah yang diselesaikan yaitu mendapatkan nilai akhir terbaik dengan tidak lagi menggunakan penilaian secara subyektif.

2. Menyusun hierarki yang diawali dengan tujuan utama

Dimulai dengan menentukan tujuan dari pembuatan sistem ini, lalu menentukan kriteria dan alternatif yang dinilai dan diurutkan berdasarkan prioritas.

Tujuan utama penelitian ini adalah membuat sebuah sistem penunjang keputusan penentuan guru terbaik. Sedangkan kriteria yang dinilai adalah :

a. Pedagogik

Kriteria ini menunjukkan bagaimana seorang guru dalam memberikan strategi pembelajaran kepada peserta didik. Kriteria pedagogik memiliki sub kriteria antara lain:

1. Menguasai karakter peserta didik (SKRT1)

2. Menguasai teori belajar dan prinsipprinsip pembelajaran yang mendidik (SKRT2)

3. Kegiatan pembelajran yang mendidik (SKRT3)

4. Memahami dan mengembangkan potensi (SKRT4)

5. Komunikasi dengan peserta didik (SKRT5)

6. Penilaian dan evaluasi (SKRT6)

7. Pengembangan kurikulum (SKRT7)

b. Kepribadian

Kriteria ini memiliki sub kriteria antara lain:

1. Bertindak sesuai dengan norma yang berlaku di Indonesia (SKRT8)

2. Menunjukan pribadi yang dewasa dan teladan (SKRT9)
3. Etos kerja, tanggung jawab tinggi, rasa bangga menjadi guru (SKRT10).

c. Sosial

Merupakan kemampuan seorang guru dalam berinteraksi dan berkomunikasi dengan peserta didik dan orang tua/wali peserta didik. Kriteria ini memiliki 2 sub kriteria, diantaranya:

1. Bersikap Inklusif, Bertindak objektif, serta tidak diskriminatif (SKRT11)

2. Komunikasi antar rekan sejawat, Orang tua/wali murid, siswa \& masyarakat (SKRT12)

d. Profesional

Merupakan penilaian kinerja guru yang menunjukan sikap professional di sekolah dalam segi perencanaan pembelajaran secara luas, penguasaan kurikulum mata pelajaran. Professonal memiliki 2 sub kriteria, diantaranya yaitu:

1. Penguasaan materi struktur konsep \& pola pikir keilmuan yang mendukung mata pelajaran yang diampu (SKRT13)

2. Mengembangkan keprofesian melalui tindakan reflektif. (SKRT14)

3. Menentukan data alternatif

Data alternatif berasal dari guru SMPN 10 Tangerang yang akan dinilai berdasarkan kriteria Pedagogik, Kepribadian, Sosial, Profesional. Pada penelitian ini terdapat 5 orang guru sebagai alternatif yaitu Tati Sukmawati(GR1), Ida Maulidia(GR2), Aan Nuryanah(GR3), Dedy Suryadi(GR4), dan Novita Nurul Aini(GR1).

4. Membuat nilai perbandingan berpasangan

Nilai perbandingan berpasangan akan dijabarkan kedalam bentuk nilai matriks. Matriks ini diperoleh dari kuisioner yang telah diisi oleh kepala sekolah sehingga mendapatkan tingkat perbandingan kepentingan antar kriteria. Skala penilaian antara elemen yang dinilai adalah 1-9. Berikut adalah hasil nilai perbandingan kepentingan antar kriteria :

Tabel 1. Matriks Perbandingan Pedagogik

\begin{tabular}{llllllll}
\hline $\begin{array}{l}\text { Sub } \\
\text { Kriteria }\end{array}$ & \multicolumn{6}{l}{ SKRT1SKRT2SKRT3SKRT4SKRT5SKRT6SKRT7 } \\
\hline SKRT1 & 1 & 1 & 3 & $1 / 2$ & $1 / 2$ & $1 / 2$ & 2 \\
SKRT2 & 1 & 1 & 1 & $1 / 2$ & $1 / 3$ & $1 / 3$ & 1 \\
SKRT3 & $1 / 3$ & 1 & 1 & $1 / 5$ & 1 & $1 / 3$ & 2 \\
SKRT4 & 2 & 2 & 5 & 1 & 3 & 1 & 1 \\
SKRT5 & 2 & 3 & 1 & 3 & 1 & 1 & 1 \\
SKRT6 & 2 & 3 & 3 & 1 & 1 & 1 & 1 \\
SKRT7 & $1 / 2$ & 1 & $1 / 2$ & 1 & 1 & 1 & 1 \\
\hline
\end{tabular}


Tabel 2. Matriks Perbandingan Kriteria Kepribadian

\begin{tabular}{llll}
\hline Sub Kriteria & SKRT8 & SKRT9 & SKRT10 \\
\hline SKRT8 & 1 & 3 & $1 / 2$ \\
SKRT9 & $1 / 3$ & 1 & $1 / 4$ \\
SKRT10 & 2 & 4 & 1 \\
\hline
\end{tabular}

Tabel 3. Matriks Perbandingan Kriteria Sosial

\begin{tabular}{lll}
\hline Sub Kriteria & SKRT11 & SKRT12 \\
\hline SKRT11 & 1 & $1 / 3$ \\
SKRT12 & 3 & 1 \\
\hline
\end{tabular}

Tabel 4. Matriks Perbandingan Kriteria Profesional

\begin{tabular}{lll}
\hline Sub Kriteria & SKRT13 & SKRT14 \\
\hline SKRT13 & 1 & $1 / 6$ \\
SKRT14 & 6 & 1 \\
\hline
\end{tabular}

Dari matriks perbandingan tersebut, lalu langkah selanjutnya yaitu menjabarkan tabel 1 , tabel 2, tabel 3, tabel 4 kedalam matriks decimal. Contoh penjabaran matriks decimal dari kriteria pedagogik :

Tabel 5. Matriks bilangan decimal kriteria pedagogik

$\begin{aligned} & \text { Sub } \\
& \text { Kriteri } \\
& \text { a }\end{aligned}$
\begin{tabular}{llllllll} 
SKRT1 & 1,0000 & 1,0000 & 3,0000 & 0,5000 & 0,5000 & 0,50000 & 2,0000 \\
SKRT2 & 1,0000 & 1,0000 & 1,0000 & 0,5000 & 0,3333 & 0,3333 & 1,0000 \\
SKRT3 & 0,3333 & 1,0000 & 1,0000 & 0,2000 & 1,0000 & 1,0000 & 2,0000 \\
SKRT4 2,0000 & 2,0000 & 5,0000 & 1,0000 & 3,0000 & 3,0000 & 1,0000 \\
SKRT5 2,0000 & 3,0000 & 1,0000 & 3,0000 & 1,0000 & 1,0000 & 1,0000 \\
SKRT6 2,0000 & 3,0000 & 3,0000 & 1,0000 & 1,0000 & 1,0000 & 1,0000 \\
SKRT7 0,5000 & 1,0000 & 0,5000 & 1,0000 & 1,0000 & 1,0000 & 1,0000 \\
\hline
\end{tabular}

5. Membuat matriks berpasangan

Perbandingan berpasangan (pairwaise comparison) yaitu membandingkan setiap elemen dengan elemen lainnya pada setiap tingkat hirarki secara berpasangan sehingga didapat nilai tingkat kepentingan elemen dalam bentuk pendapat kualitatif. Perbandingan ini dilakukan untuk setiap kriteria dan alternatif. Nilai matriks berpasangan diperoleh dengan mengkalikan tabel matriks decimal (tabel 5) dengan dirinya sendiri Tabel 6 adalah hasil perkalian berpasangan pada kriteria pedagogik beserta sub kriteria yang ada didalamnya :

Tabel 6. Matriks hasil perkalian kriteria pedagogik dengan dirinya sendiri

\begin{tabular}{lllllll}
\hline $\mathbf{7 , 0 0 0 0}$ & $\mathbf{1 1 , 0 0 0 0}$ & $\mathbf{1 2 , 5 0 0 0}$ & $\mathbf{4 , 7 6 6 7}$ & $\mathbf{8 , 3 3 3 3}$ & $\mathbf{1 2 , 5 0 0 0}$ & $\mathbf{1 2 , 5 0 0 0}$ \\
\hline 5,1667 & 7,0000 & 9,3333 & 3,1444 & 5,0000 & 3,3333 & 7,1667 \\
5,7333 & 8,7333 & 7,0000 & 3,7333 & 5,4333 & 4,3667 & 7,2000 \\
16,1667 & 24,0000 & 24,5000 & 7,0000 & 14,6667 & 9,3333 & 22,0000 \\
10,5000 & 13,6667 & 16,1667 & 5,3667 & 7,0000 & 5,6667 & 12,3333 \\
12,50000 & 17,0000 & 21,5000 & 6,4333 & 11,0000 & 7,0000 & 17,0000 \\
8,1667 & 11,0000 & 12,5000 & 4,1833 & 7,0000 & 4,7500 & 7,0000 \\
\hline
\end{tabular}

6. Menormalkan data

Penormalan data dilakukan dengan menjumlahkan setiap elemen baris pada matriks. Hasil normalisasi pada tabel 6 yaitu : nilai SKRT1 =61,4333, nilai SKRT2=40,1444, nilai SKRT3 $=42,2000$, nilai SKRT4 $=117,6667$, nilai SKRT5=70,7000, nilai SKRT6=92,4333, nilai SKRT7=54,6833. Dan total nilai keseluruhan dari kriteria pedagogik yang dinormalkan adalah sebesar 479,2611.

Penormalan data dilakukan dengan menjumlahkan setiap elemen baris pada matriks. Hasil normalisasi pada tabel 6 yaitu : nilai SKRT1 =61,4333, nilai SKRT2 $=40,1444$, nilai SKRT3 $=42,2000$, nilai SKRT4 $=117,6667$, nilai SKRT5=70,7000, nilai SKRT6=92,4333, nilai SKRT7=54,6833. Dan total nilai keseluruhan dari kriteria pedagogik yang dinormalkan adalah sebesar 479,2611.

7. Menghitung nilai Eigenvector dan menguji nilai konsistensinya

Yaitu dengan membagi nilai dari setiap elemen matriks berpasangan dengan total keseluruhan dari setiap kolom. Apabila nilai Eigenvector tidak konsisten makan pengambilan data harus diulangi lagi hingga mendapatkan nilai yang maksimal. Nilai eigenvector yang diperoleh pada tabel 6 yaitu : nilai SKRT1 $=0,1282$, nilai SKRT2=0,0838, nilai SKRT3 $=0,8881$, nilai $\quad$ SKRT4 $=0,2455$, nilai SKRT5 $=0,1475$, nilai $\quad$ SKRT6 $=0,1929$, nilai SKRT7=0,1141. Sehingga ketika dijumlahkan maka menghasilkan nilai konsisten sebesar 1,0000. Langkah ini juga dilakukan pada kriteria yang lain dan menghasilkan nilai konsistensi yang sama dengan kriteria pedagogik. Hasil eigenvector ini yang digunakan dalam perhitungan SAW.

8. Menguji konsistensi hierarki

Pengujian dilakukan dengan menghitung nilai Consistency Index(CI) dan Consistency Ratio(CR). Syarat nilai dianggap konsisten apabila nilai Consistency Ratio(CR) < 0,1. Jika tidak memenuhi maka dilakukan penilaian ulang.

a. Langkah 1, mengkalikan nilai pada matriks decimal dengan nilai eigenvector .

b. Langkah 2, menghitung consistency vector dengan cara membagi hasil pada langkah 1 dengan dengan nilai eigenvector sehingga menghasilkan : nilai SKRT1 $=0,9973: 0,1282=7,7799$ nilai SKRT2 $=0,6503: 0,0838=7,7638$ nilai SKRT3 $=0,7037: 0,0881=7,9913$ nilai SKRT4 $=1,8592: 0,2455=7,5726$ nilai SKRT5 $=1,1320: 0,1475=7,6738$ nilai SKRT6 $=1,4718: 0,1929=7,6313$ nilai SKRT7 $=0,8919: 0,1141=7,8167$

c. Langkah 3, menentukan nilai rata-rata consistency vector dengan cara membagi 
keseluruhan nilai consistency vector dengan jumlah kriteria. Sehingga nilai rata-rata consistency vector pada kriteria pedagogik dengan jumlah sub kriteria sebanyak 7 sub, adalah sebesar $=7,7471$.

d. Langkah 4, menghitung CI (Consistency Index) :

$$
C H=\frac{x-n}{n-1}
$$

Persamaan (1) :

CI = Rasio penyimpangan (deviasi) konsistensi (consistency index)

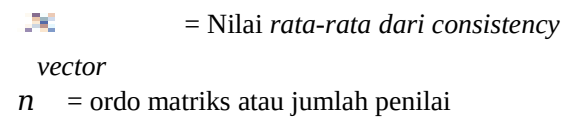

Berikut adalah contoh perhitungan consistency index untuk kriteria pedagogik. 0,1245

$\mathrm{CI}($ kriteria pedagogik $)=(7,7471-7) \div(7-1)=$

e. Langkah 5, menghitung CR (Consistency Ratio) :

Untuk menghitung CR dibutuhkan Nilai Random Index (RI). Nilai RI merupakan nilai yang dikeluarkan oleh Oarkridge Laboratory (Tabel 7) :

Tabel 7. Nilai Random Index

\begin{tabular}{llllll}
\hline $\mathbf{N}$ & $\mathbf{R I}$ & $\mathbf{N}$ & $\mathbf{R I}$ & $\mathbf{N}$ & $\mathbf{R I}$ \\
\hline 1 & 0,00 & 6 & 1,24 & 11 & 1,51 \\
2 & 0,00 & 7 & 1,32 & 12 & 1,48 \\
3 & 0,58 & 8 & 1,41 & 13 & 1,56 \\
4 & 0,90 & 9 & 2,45 & 14 & 1,58 \\
5 & 1,12 & 10 & 1,49 & 15 & 1,59 \\
\hline
\end{tabular}

Sehingga untuk kriteria pedagogik dengan menggunakan 7 sub kriteria, maka nilai RI yang digunakan adalah : 1,32.

Rumus CR adalah:

$$
\mathrm{CF}=\frac{\mathrm{EI}}{\mathrm{RI}}
$$

Persamaan (2) :

$\mathrm{CI}=$ Consistency Index

$\mathrm{RI}=$ Random Index

Contoh perhitungan data CR(kriteria pedagogik) $=0,1245 / 1,32=0,0943$

Hasil perhitungan CI(kriteria pedagogik) dan $\mathrm{CR}$ (kriteria pedagogik) adalah $<0.1$, sehingga dapat disimpulkan bahwa nilai dari matriks yang berpasangan adalah konsisten. Untuk pengujian data kriteria kepribadian, sosial dan profesional menggunakan langkah yang sama seperti menghitung bobot dari kriteria pedagogik dan di uji sehingga menghasilkan nilai akhir yang konsisten.

\subsection{Metode Simple Additive Weighting (SAW).}

Metode ini sering juga disebut metode penjumlahan terbobot . Metode ini digunakan untuk mencari penjumlahan terbobot dari rating kinerja pada setiap alternatif pada semua atribut . Tahapan yang dilakukan antara lain :

1. Melakukan normalisasi

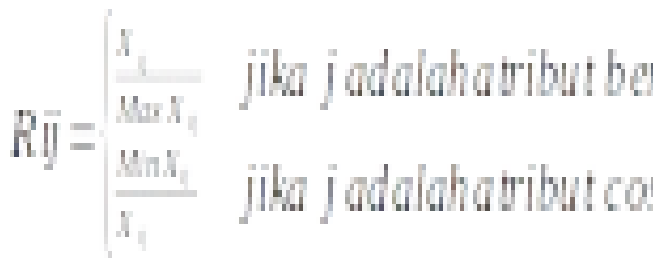

$$
\begin{aligned}
& \text { Persamaan (3): } \\
& \begin{aligned}
\text { Rij = Rating kinerja ternormalisasi } \\
\text { Maxij= Nilai maksimum dari setiap baris dan } \\
\text { kolom }
\end{aligned} \\
& \begin{aligned}
\text { Minij }=\text { Nilai minimum dari setiap baris dan } \\
\text { kolom }
\end{aligned} \\
& \begin{aligned}
\text { Xij }=\text { Baris dan kolom dari matriks Dengan Rij } \\
\text { adalah rating kinerja ternormalisasi dari } \\
\text { alternatif Ai pada atribut Cj; }
\end{aligned} \\
& \begin{array}{l}
\mathrm{i}=1,2, \ldots \text { m dan } \mathrm{j}=1,2, \ldots, \mathrm{n} . \\
\text { Benefit }=\text { Jika nilai terbesar terbaik } \\
\text { Cost = Jika nilai terkecil terbaik }
\end{array}
\end{aligned}
$$

Tabel 8. Nilai alternatif pada kriteria padegogik

\begin{tabular}{llllllll}
\hline $\begin{array}{l}\text { Alterna } \\
\text { tif }\end{array}$ & \multicolumn{7}{l}{ SKRT1 SKRT2 SKRT3 SKRT4 SKRT5 SKRT6 SKRT7 } \\
\hline GR1 & 3 & 4 & 4 & 4 & 4 & 4 & 3 \\
GR2 & 3 & 3 & 4 & 3 & 3 & 4 & 3 \\
GR3 & 3 & 3 & 3 & 4 & 4 & 4 & 3 \\
GR4 & 3 & 4 & 4 & 4 & 4 & 2 & 4 \\
GR5 & 3 & 3 & 3 & 4 & 3 & 3 & 3 \\
\hline
\end{tabular}

Tabel 9. Nilai matriks normalisasi pada kriteria padegogik

\begin{tabular}{lllllllll}
\hline $\begin{array}{l}\text { Alterna } \\
\text { tif }\end{array}$ & \multicolumn{1}{l}{ SKRT1 SKRT2 SKRT3 SKRT4 SKRT5 SKRT6 SKRT7 } \\
\hline GR1 & 1,0000 & 1,0000 & 1,0000 & 1,0000 & 1,0000 & 1,0000 & 0,7500 \\
GR2 & 1,0000 & 0,7500 & 1,0000 & 0,7500 & 0,7500 & 1,0000 & 0,7500 \\
GR3 & 1,0000 & 0,7500 & 0,7500 & 1,0000 & 1,0000 & 1,0000 & 0,7500 \\
GR4 & 1,0000 & 1,0000 & 1,0000 & 1,0000 & 1,0000 & 0,5000 & 1,0000 \\
GR5 & 1,0000 & 0,7500 & 0,7500 & 1,0000 & 0,7500 & 0,7500 & 0,7500 \\
Bobot & 0,1282 & 0,0838 & 0,0881 & 0,2455 & 0,1475 & 0,1929 & 0,1141 \\
\hline
\end{tabular}

2. Setelah nilai matriks ternormalisasi (R) didapat, langkah selanjutnya adalah proses nilai preferensi untuk setiap guru dengan persamaan sebagai berikut:

$$
V_{1}=\sum w^{n}
$$

Persamaan (4):

$\mathrm{Vi}=$ Rank untuk setiap alternatif

$\mathrm{Wj}=$ Nilai bobot dari setiap kriteria

$\mathrm{Rij}=$ Nilai rating kinerja ternormalisasi 
Berdasarkan tabel 9, nilai preferensi yang diujikan terharhap 5 guru sebagai berikut :

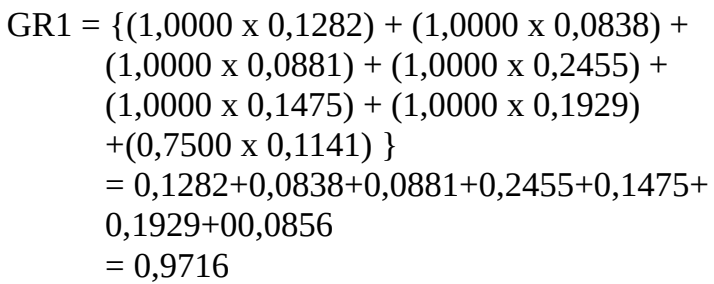

Sehingga nilai preferensi yang diperoleh dari semua kriteria adalah sebagai berikut :

Tabel 10. Total penjumlahan dan perkalian alternatif

\begin{tabular}{llllll}
\hline $\begin{array}{l}\text { Guru/ } \\
\text { Kriteria gogik }\end{array}$ & $\begin{array}{l}\text { Peda- } \\
\text { dian }\end{array}$ & Sosial & $\begin{array}{l}\text { Profesi- } \\
\text { onal }\end{array}$ & Jumlah \\
\hline GR1 & 0,9716 & 1,0000 & 1,0000 & 0,7143 & 3,6859 \\
GR2 & 0,8524 & 0,8299 & 0,9375 & 0,7143 & 3,3341 \\
GR3 & 0,9287 & 0,8601 & 0,7500 & 1,0000 & 3,5387 \\
GR4 & 0,9037 & 0,8601 & 0,7500 & 0,7143 & 3,2281 \\
GR5 & 0,8435 & 1,0000 & 0,7500 & 1,0000 & 3,5935 \\
\hline
\end{tabular}

Berdasarkan tabel 10, maka peringkat yang diperoleh :
Ranking 1 adalah GR1, Ranking 2 adalah GR5, Ranking 3 adalah GR3, Ranking 4 adalah GR2 dan Ranking 5 adalah GR4.

\subsection{Model Data}

Merupakan struktur record yang terbentuk dari hasil himpunan antar entitas-entitas.

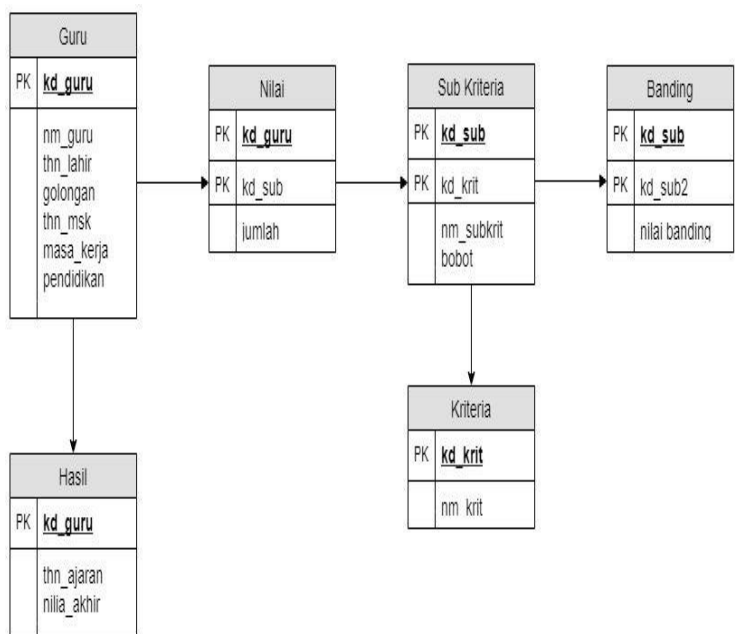

Gambar 1. Model Data Sistem Penunjang Keputusan Penentuan Guru Terbaik

Gambar 1 menjelaskan entitas-entitas yang digunakan dalam sistem penunjang keputusan ini antara lain : Guru, Nilai, Kriteria, SubKriteria, Banding, dan Hasil.

\subsection{Rancangan Layar Sistem}

Gambar 2, salah satu rancangan layar program menginput nilai perbandingan sub kriteria.

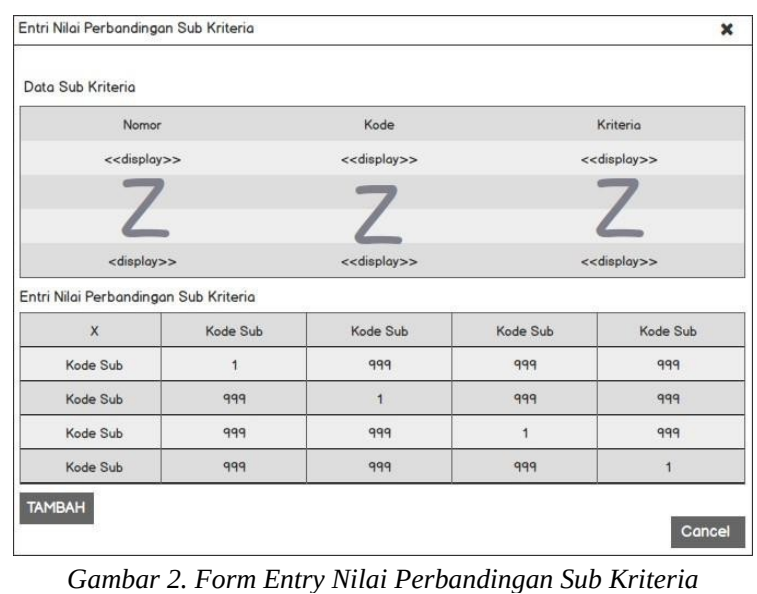

\section{KESIMPULAN}

Penggunaan metode Analytical Hierarchy Process (AHP) sebagai penentuan bobot dari kriteria dan subkriteria yang digunakan menghasilkan nilai Consistency Index dan Consistency Ratio yang konsisten karena tidak lebih dari 0,1. Sedangkan 
metode Simple Additive Weighting (SAW) dalam menentukan guru terbaik berdasarkan nilai akhir yang objektif sesuai dengan nilai eigenvector masing-masing kriteria dan sub kriteria yang sudah ditentukan, sehingga proses penilaian guru terbaik terhindar dari adanya penilaian yang subjektif.

\section{DAFTAR PUSTAKA}

[1] E. Choliviana, "Pembuatan Sistem Informasi Pendaftaran Siswa Baru Pada Madrasah Ibtidaiyah Muhammadiyah Wonoanti III,” IJCSS, vol. 5, no. 1, pp. 6-14, 2013.

[2] D. Nofriansyah, Konsep Data Mining Vs Sistem Pendukung Keputusan. 2015.

[3] Ardiansyah, M Opy, and KristianSiregar, "Implementasi Sistem Pendukung Keputusan Pemilihan Siswa Berprestasi Menggunakan Metode Analitic Hierarchy Process (AHP) pada SMK Negeri Rundeng,” Pelita Inform. Budi Darma, vol. 15, no. 1, pp. 12-18, 2016.

[4] W. R. Hasibuan, "Sistem Pendukung Keputusan Dalam Menentukan Jenis Tanaman Pada Lahan Pertanian Dengan Menggunakan Metode Simple Additive Weighting (SAW),” Agrium, vol. 20, no. 2, pp. 157-162, 2016.

[5] Frieyadie, "Penerapan Metode Simple Additive Weight (SAW) Dalam Sistem Pendukung Keputusan Promosi Kenaikan Jabatan,” J. Pilar Nusa Mandiri, vol. 12, no. 1, pp. 37-45, 2016. 